\section{Tinjauan Pustaka}

\section{HUBUNGAN ANTARA TIPE POLA ASUH DAN DEPRESI PADA REMAJA}

\author{
Ajeng Ardhya Ramadhanti ${ }^{1}$ \\ ${ }^{1}$ Pendidikan Dokter, Fakultas Kedokteran, \\ Universitas Lampung
}

\begin{abstract}
ABSTRAK
Pendahuluan: Depresi merupakan gangguan suasana hati yang berubah-ubah pada diri seseorang dalam kurun waktu tertentu yang akan menimbulkan perubahan pada kondisi psikis maupun fisiologis tubuh. Depresi pada remaja dapat dipengaruhi berbagai faktor, salah satunya pola asuh. Berdasarkan penelitian terdahulu ditemukan 8 studi yang menguatkan bukti hubungan antara pola asuh dengan depresi pada remaja, sehingga peneliti ingin mengidentifikasi lebih lanjut tipe pola asuh yang dinilai berhubungan dengan tingkat depresi pada remaja. Tujuan penulisan artikel adalah untuk megidentifikasi tipe pengasuhan yang yang paling sedikit menyumbang depresi pada remaja.

Metode: Artikel ini dibuat dengan metode literature review yang melibatkan 8 artikel jurnal yang dipublikasi secara nasional maupun internasional selama 10 tahun terakhir dengan bahasan yang relevan mengenai pola asuh dan depresi pada remaja dan didapatkan melalui Google Scholar dan Pubmed berdasarkan kriteria inklusi.Teknik analisis data dilakukan dilakukan secara deskriptif kualitatif, yaitu melakukan analisis terhadap hasil dari jurnal yang didapat tanpa melakukan uji statistik.

Pembahasan: Pola asuh merupakan cara pengasuhan orang tua terhadap anak yang meliputi dukungan dan kepedulian kepada anak, yang berpengaruh terhadap masa depan mereka. Pola asuh dikategorikan menjadi pola asuh demokratis, permisif, dan otoriter. Bentuk dukungan, motivasi, dan/atau kasih sayang dari orang tua kepada anak akan memengaruhi kesehatan mental dan dapat menjadi faktor penyebab timbulnya depresi ketika memasuki usia remaja.

Simpulan: Pola pengasuhan demokratis dinilai sebagai pola pengasuhan anak yang terbaik. Pola pengasuhan demokratis dapat membentuk kepribadian dan kondisi psikis anak, terutama di usia remaja. Studi sebelumnya yang diulas dalam artikel ini tidak menjelaskan intervensi yang diberikan. Dukungan orang tua dan pola pengasuhan anak yang tepat diharapkan dapat diupayakan untuk menjadi bagian dari budaya di masyarakat sehingga menekan tingginya angka kejadian depresi pada remaja.
\end{abstract}

Kata Kunci: depresi, pola asuh, remaja.

\title{
ASSOCIATION OF PARENTING STYLES AND ADOLESCENT DEPRESSION
}

\begin{abstract}
Introduction: Depression is a mood disorder that changes in a person within a certain time which will cause changes in the psychological and physiological conditions of the body. Depression in adolescents can be influenced by various factors, one of which is parenting. Based on previous research found 8 studies that strengthen the evidence of the relationship between parenting with depression in adolescents, so researchers want to further identify the type of parenting that is judged to be related to depression rates in adolescents. The purpose of writing articles is to identify the type of care that contributes the least to depression in adolescents.
\end{abstract}

Method: This article was created using a literature review method involving 8 journal 
articles published nationally and internationally over the past 10 years with relevant discussions on parenting and depression in adolescents and obtained through Google Scholar and Pubmed based on inclusion criteria. Data analysis techniques were performed Qualitative descriptive, which is to analyze the results of the journals obtained without doing statistical tests.

Discussion: Parenting is a way of parenting parents for children which includes support and care for children, which affects their future. Parenting is categorized as democratic, permissive, and authoritarian. Forms of support, motivation, and / or affection from parents to children will affect mental health and can be a factor causing depression when entering adolescence.

Conclusion: Democratic parenting is considered as the best parenting pattern. Democratic parenting can shape the personality and psychological condition of children, especially in their teens. Previous studies reviewed in this article do not explain the interventions provided. Parental support and appropriate childcare patterns can become part of the culture in the community, thereby suppressing the high incidence of depression in adolescents.

Keywords: depression, parenting, adolescent

\section{PENDAHULUAN}

Depresi merupakan gangguan suasana hati yang berubah-ubah pada diri seseorang dalam kurun waktu tertentu dan dapat mengena kepada siapa saja. Depresi adalah gangguan mental yang serius dan sering terjadi yang dapat menyebabkan dampak negatif terhadap perasaan, pola pikir dan tingkah laku (American Psychiatric Association, 2013).[1] Depresi dapat terjadi karena adanya beberapa faktor risiko, diantaranya adalah biokimia, genetik, kepribadian, dan faktor lingkungan. Menurut National Institute of Mental Health (2016), tanda dan gejala seseorang terkena depresi bukan hanya merasakan kesedihan, namun juga perubahan pada suasana hati atau perasaan lainnya seperti perasaan cemas, pesimis, rasa gelisah, sensitif dan mudah tersinggung, perasaan bersalah dan tidak berdaya, mengalami kelelahan yang berarti, penurunan konsentrasi, perubahan nafsu makan yang berdampak pada penurunan berat badan, mengalami kesulitan tidur serta muncul gejala kram, nyeri atau gangguan pencernaan tanpa sebab yang jelas. ${ }^{[2]}$

Depresi secara garis besar dapat dikategorikan menjadi dua, Depresi Mayor (Major Depression) dan Gangguan Depresi Persisten (Persistent Depressive Disorder) yang dapat disebut juga sebagai dysthimia. Depresi dapat terjadi pada semua kelompok umur dan jenis kelamin. Remaja merupakan kelompok umur yang rentan mengalami depresi, sebab usia remaja adalah usia yang sensitif di mana pada masa ini terjadi perubahan (pubertas) pada tubuh dan pada masa ini pula mereka mulai mengenal dengan berbagai masalah dalam hidup. ${ }^{[3]}$ Menurut World Health Organization (2017) lebih dari 322 juta orang di semua rentang usia di dunia mengalami depresi, dengan estimasi prevalensi pada usia 15 - 19 tahun berkisar 4,5\% pada perempuan dan $3,2 \%$ pada laki-laki. ${ }^{[4]}$ Menurut data Riset Kesehatan Dasar (2018), kejadian depresi di Indonesia memiliki prevalensi $61 \%$ pada kelompok usia $>15$ tahun. Hasil tersebut juga menjelaskan bahwa prevalensi depresi pada perempuan lebih tinggi $(7,4 \%)$ daripada laki-laki $(4,7 \%)$, sehingga dapat diketahui bahwa depresi dinilai lebih rentan untuk dialami perempuan jika dibandingkan dengan laki-laki.[5]

Studi mengenai pola asuh dan tingkat depresi pada remaja yang dilakukan oleh Tujuwale et al. (2016) pada siswa di SMA Negeri 1 Amurang menyebutkan dinilai terdapat hubungan antara pola asuh dengan tingkat depresi remaja.[6] Penelitian ini menyasar 91 responden dengan rentang usia 14 tahun $(7,7 \%), 15$ tahun $(79,1 \%)$, dan 16 tahun $(13,2 \%)$ dengan jenis kelamin laki-laki $(37,4 \%)$ maupun perempuan $(62,6 \%)$. Berdasarkan hasil penelitian tersebut diketahui bahwa sebanyak 21 responden $(23,1 \%)$ tidak memiliki depresi (normal), sedangkan sisanya sebanyak 31 responden $(34,1 \%)$ depresi ringan, 25 responden $(27,4 \%)$ depresi sedang, 14 responden $(15,4 \%)$ depresi berat. Pola 
asuh orangtua secara mayoritas adalah demokratis $(49,4 \%)$, diikuti otoriter $(26,4 \%)$, dan permisif $(24,2 \%)$. Berdasarkan hal tersebut diketahui bahwa siswa remaja dengan tingkat depresi ringan lebih banyak daripada yang tidak depresi, mengalami depresi pada tingkatan sedang maupun berat. Pola asuh demokratis merupakan hasil jenis pola asuh terbanyak yang didapatkan jika dibandingkan dengan pola asuh otoriter dan permisif.

$$
\text { Penelitian serupa yang }
$$

dilakukan oleh Safitri \& Hidayati (2013) juga mendapatkan hasil yang sama, yaitu pola asuh diduga berkontribusi dalam terjadinya depresi pada remaja..7] Berdasarkan penelitian yang dilakukan di SMK 10 Nopember Semarang, diketahui bahwa mayoritas siswa (106 siswa) mengalami depresi ringan dan sisanya (26 siswa mengalami depresi tingkat sedang. Berdasarkan distribusi tingkat depresi dengan pola asuh, diketahui bahwa pada tingkat depresi ringan, 1 siswa mendapat pola asuh otoriter dan permisif; 72 siswa mendapat pola asuh demokratis; 31 siswa mendapat pola asuh campuran. Tingkat depresi sedang pada 9 siswa mendapat pola asuh otoriter dan permisif; 11 siswa mendapat pola asuh demokratis; dan sisanya (6 siswa) mendapat pola asuh campuran.

Menurut penelitian yang dilakukan Arsyam \& Murtiani (2017) dengan subyek siswa SMAN 1 Sinjai Timur diketahui bahwa berdasarkan diduga pola asuh dapat berkontribusi terhadap kejadian depresi pada remaja. ${ }^{[8]}$ Berdasarkan total 136 responden, didapatkan hasil bahwa 59 siswa tidak depresi dan 77 siswa mengalami depresi dengan berbagai macam pola asuh meliputi demokratis, permisif, dan otoriter.

Berdasarkan

penelitianpenelitian di atas, dapat dinilai terdapat hubungan antara pola asuh dengan tingkat depresi. Pola asuh dapat diklasiifkasikan menjadi 3 jenis, yaitu pola asuh demokratis, pola asuh permisif, dan pola asuh otoriter (Stewart \& Koch, 1983). ${ }^{[9]}$ Pola asuh tersebut memiliki peran terhadap tingkat depresi pada remaja sehingga berdasarkan urgensi di atas penulis tertarik untuk melakukan telaah guna mengetahui hubungan pola asuh dengan kejadian depresi pada remaja. Harapannya melalui studi literatur ini dapat diidentifikasi tipe pola pengasuhan yang paling sedikit menyumbang depresi pada remaja, mengingat kondisi depresi pada remaja akan membawa dampak dalam segi psikologis maupun fisiologis dalam jangka pendek maupun jangka panjang.

\section{METODE}

Artikel ini ditulis menggunakan metode telaah literatur (literature review) dengan melakukan penelusuran terhadap artikel atau jurnal pada Google Scholar dan Pubmed sesuai variabel yang telah ditetapkan sebelumnya. Adapun variabel dalam artikel ini terdiri dari variabel bebas, yaitu pola asuh dan variabel terikat, yaitu depresi pada remaja. Kriteria inklusi yang ditetapkan adalah: jurnal nasional atau internasional yang diterbitkan dalam 10 tahun terakhir, berbahasa Indonesia maupun bahasa inggris dan mengulas tentang hubungan pola asuh dengan depresi pada remaja. Berdasarkan pencarian yang dilakukan, terdapat 23 studi yang kemudian dipilah sesuai kriteria inklusi dan didapatkan 8 hasil studi. Teknik analisis data dilakukan dilakukan secara deskriptif kualitatif, yaitu melakukan analisis berdasarkan jurnal yang relevan yaitu 8 jurnal tanpa melakukan uji statistik.

\section{PEMBAHASAN}

Remaja adalah masa pertumbuhan yang kritis (Beardslee et al., 2012) sehingga masalah psikososial pada masa ini sangat mungkin untuk terjadi (Braveman, 2014). ${ }^{[10,11]}$ Seringkali pada masa remaja tersebut terjadi perubahan pola pikir (psikis) dan fisiologis, sehingga pada masa ini pula cenderung terjadi gangguan psikologis, termasuk depresi. Kieling et al. (2011) menjelaskan bahwa masalah kesehatan mental terutama pada remaja adalah masalah kesehatan masyarakat yang mendesak. ${ }^{[12]} \mathrm{Hal}$ ini sesuai dengan penelitian sebelumnya bahwa depresi pada remaja dalam beberapa tahun terakhir mengalami peningkatan, yang 
sesuai dengan penilitian Mojtabai et al. (2016) pada studi yang dilakukan pada 172.495 remaja di usia 12 hingga 17 tahun di Amerika Serikat yang menunjukkan hasil peningkatan prevalensi dari awalnya 8,7\% (2005) menjadi sebesar $11,3 \%$ (2014). [13]

Penelitian lain yang dilakukan oleh Seon \& Oh (2013) menyatakan bahwa faktor peran orang tua yang termasuk dalam faktor lingkungan dapat memberikan dampak yang signifikan pada remaja. [14] Masa-masa rentan pada saat remaja tersebut dapat menyebabkan gangguan psikis, yang salah satu dampaknya dapat menyebabkan depresi. Depresi pada masa remaja dapat membawa banyak perubahan psikologis yang selanjutnya dapat memengaruhi perilaku dan sikap remaja dalam jangka pendek maupun jangka panjang.

Depresi pada remaja perempuan lebih rentan daripada laki-laki, dikarenakan adanya perubahan hormon yang berpengaruh terhadap perubahan suasana hati. Hal ini sesuai dengan penelitian Bauman et al. (2013) yang menyatakan bahwa peluang remaja perempuan untuk mengalami depresi 1,73 kali lebih besar dibandingkan lakilaki.[15] Lebih lanjut National Institute Mental Health (2011) menyatakan bahwa emosi dan suasana hati dipengaruhi oleh hormon yang bekerja pada otak,[2] sehingga dapat disimpulkan bahwa remaja perempuan lebih rentan untuk mengalami depresi dikarenakan bawaan faktor internal diri pada perempuan, disamping faktor lingkungan dan faktor lainnya.

Penelitian yang dilakukan oleh Sriyanto et al. (2014) menjelaskan bahwa unsur pendidikan yang memengaruhi model tumbuh kembang anak baik secara langsung maupun tidak langsung adalah kepribadian orang tua, sikap, dan cara hidup. [16] Hal ini sesuai dengan penelitian Anli, I. \& Karsl, T.A. bahwa perilaku ibu atau ayah memiliki konsekuensi terhadap kualitas kesehatan mental anak-anak mereka dan akan berpengaruh terhadap psikopatologi mereka. ${ }^{[17]}$ Semakin beranjak usia, anak akan mengerti dengan apa yang terjadi di lingkungan sekitarnya, termasuk kepribadian orang tua dan pola asuh yang diterapkan, namun tidak semua orang tua menyadari bahwa pola asuh akan berpengaruh terhadap tumbuh kembang anak, terutama dari segi perkembangan psikis dan kepribadian. Sering kali orang tua tidak sadar bahwa terjadi kontradiksi dan penyimpangan pola asuh yang akan berdampak cukup besar bagi perkembangan kepribadian anak, baik secara positif maupun negatif (Anisah, 2011).[18]

Perilaku orang tua terhadap pola pengasuhan anak dapat menjadi faktor penghambat maupun faktor pencetus untuk terjadinya depresi (Chapman, 2016).[19] Studi yang dilakukan sebelumnya (Wang \& Muhtadie) menjelaskan jika pola asuh yang cenderung bijaksana dapat berdampak bagi penurunan tingkat depresi di masa kanak-kanak, sebaliknya jika pola asuh otoriter dapat meningkatkan depresi pada anak. ${ }^{[20,21]}$ Pola asuh demokratis merupakan hasil jenis pola asuh terbanyak yang didapatkan jika dibandingkan dengan pola asuh otoriter dan permisif. Pola asuh demokratis memiliki hubungan yang positif terhadap perkembangan kecerdasan emosional anak, yang berkembang karena adanya dukungan dari lingkungan terutama keluarga (Septiani, 2017).[22]

Pola asuh demokratis akan mengedepankan persamaan hak dan pola pikir rasional dalam keluarga. Anak akan terbiasa untuk mengelola perasaan, pemikiran, cara pandang, dan perilaku dalam suatu hal, sehingga hal tersebut akan membentuk anak memiliki kecerdasan emosional yang baik daripada pola asuh lainnya. Pernyataan ini juga didukung penelitian yang dilakukan Novianty (2016) bahwa terdapat pengaruh antara pola asuh otoriter dengan kecerdasan emosi pada remaja madya, di mana arah hubungan adalah negatif yang artinya pola asuh otoriter berbanding terbalik dengan kecerdasan emosional remaja pada penelitian di 100 orang siswa SMASMAK di Bogor. ${ }^{[23]}$

Upaya yang dapat dilakukan agar remaja dapat terhindar dari depresi dapat disesuaikan menurut faktor penyebab 
terjadinya depresi. Adanya faktor-faktor yang dapat diubah, seperti faktor lingkungan, hendaknya dapat digunakan sebagai salah satu usaha mencegah terjadinya depresi pada remaja. Dukungan sosial terutama dari keluarga dan orang-orang terdekat akan sangat berpengaruh terhadap kesehatan mental remaja (Fitriana \& Mustafida, 2019).[24] Dukungan tersebut dapat berupa motivasi yang mendukung hal-hal yang dilakukan remaja (terutama dukungan orang tua kepada anak), dengan tetap mengarahkan pada hal-hal yang positif.

Penelitian yang dilakukan Rarasati et al. (2012), menjelaskan jika kasih sayang dan dukungan, dukungan spiritual, dukungan material, dan bimbingan adalah hal-hal yang dibutuhkan remaja dari orang tua terhadap keputusan dan masa depan mereka,[25] sehingga depresi dapat dicegah dengan memenuhi kebutuhan remaja akan kasih sayang dan dukungan dari orang-orang terdekat, terutama orang tua. Dukungan dari orang tua dapat diberikan melalui penerapan pola pengasuhan yang sesuai. Pola pengasuhan demokratis dinilai sebagai pola pengasuhan anak yang terbaik jika dibandingkan dengan pola asuh permisif dan otoriter, yang didukung oleh 5 artikel yang relevan. Pola pengasuhan demokratis dapat membentuk kepribadian dan kondisi psikis anak, terutama ketika telah memasuki usia remaja, sehingga tidak menimbulkan pertentangan terhadap kondisi psikis remaja.

\section{SIMPULAN}

Berdasarkan hasil telaah serta identifikasi dari beberapa artikel yang mengulas mengenai pola asuh dan depresi pada remaja, dapat ditarik kesimpulan bahwa tipe pola asuh dapat memengaruhi tingkat depresi pada remaja. Tipe pola asuh demokratis dinilai sebagai pola pengasuhan yang terbaik diantara ketiga pola asuh. Mengingat pentingnya kesehatan mental pada remaja serta dampak depresi dalam jangka pendek maupun jangka panjang, dukungan orang tua dan pola pengasuhan anak yang tepat diharapkan dapat diupayakan untuk menjadi bagian dari budaya di masyarakat sehingga menekan tingginya angka kejadian depresi pada remaja.

\section{DAFTAR PUSTAKA}

1. American Psychiatric Association. Diagnostic and Statistical Manual of Mental Disorders (DSM-5). Fifth Edition. 2013.

2. National Institute Mental Health. Depression. Department of Health and Human Services. 2011.

3. Argyriadis, A., Tryfonos, A., Gourni, M., Asimakopoulou E., SapountziKrepia, D., Agyriadi, A. The Emergence of Depressipn in Teenagers and The Role of Health Professionals. Health and Research Journal. 2019. 5(4),143-158.

4. WHO. Depression and Other Common Mental Disorders: Global Health Estimates. Geneva: World Health Organization; 2017.

5. Kementerian Kesehatan RI. Riset Kesehatan Dasar 2018. Jakarta: Badan Penelitian dan Pengembangan RI; 2018.

6. Tujuwale, A., Rottie, J., Wowiling, F., \& Kairupan, R. Hubungan Pola Asuh Orang Tua dengan Tingkat Depresi pada Siswa Kelas X di SMA Negeri 1 Amurang. e-Journal Keperawatan. 2016 Vol. 4 No. 1

7. Safitri, Y., \& Hidayati, E. Hubungan Antara Pola Asuh Orang Tua dengan Tingkat Depresi Remaja di SMK 10 Nopember Semarang. Jurnal Keperawatan Jiwa. 2013. Vo. 1, No. 1

8. Arsyam, S., \& Murtiani. Pola Asuh Orang Tua denga Tingkat Depresi pada Remaja. Journal of Islamic Nursing. 2017 Vol. 2, No. 1

9. Stewart, A. C., \& Koch J. Children Development through Adolescence. Canada: John Wiley \& Soon; 1983

10. Beardslee, W. R., Gladstone, T. R. G., \& OConnor E. E. Developmental risk of Depression: Experience matters. Child and Adolescent Psychiatric Clinics of North America 2012. 21 (2)

11. Braveman, $P$. What is health equity: And how does a life-course approach take us further toward it? Maternal 
and Child Health Journal, 2014. 18(2), 366-372

12. Kieling, C., Baker-Henningham, H., Belfer, M., Conti, G., Ertem, I., Omigbodun, O., et al.. Child and adolescent mental health worldwide: Evidence for action. Lancet. 2011. 378, 1515-1525

13. Mojtabai, R., Olfson, M., \& Han, B. National Trends in the Prevalence and Treatment of Depression in Adolescent and Young Adults. Pediatrics. 2016. 138(6)

14. Seon, H. Y., \& Oh, J. H. Mediating Effects Of Academic Self-Efficacy in Relations of Academic Achievement Pressure of Parents and Academic Stress.: Focused on Elementary School Students and Middle School Students. Asian Journal of Education. 2013. 14 (1)

15. Bauman, S,. Toomey R. B., \& Walker J. L. Associations among Bullying, Cyberbullying, and Suicide in High School Students. Journal of Adolescence. 2013. 36 (2)

16. Sriyanto, Abdukarim, A., Zainul, A., \& Maryani, E. Perilaku Asertif dan Kecenderungan Kenakalan Remaja Berdasarkan Pola Asuh dan Peran Media Massa. Jurnal Psikologi. 2014. Volume 41 No 1

17. Anli, I., \& Karsli, T. A. Perceived parenting style, depression and anxiety levels in a Turkish lateadolescent population. Procedia Social and Behavioral Sciences. 2010. 2, 724-727.

18. Anisah, A. S. Pola Asuh Orang Tua dan Implikasinya terhadap Pembentukan Karakter Anak. Jurnal Pendidikan Universitas Garut. 2011 Vol. 5 No. 1
19. Chapman, R., Parkinson, M., \& Halligan, S. How do parent-child interactions predict and maintain depression in childhood and adolescence? A critical review of the literature. Adolescent Psychiatry. 2016. 6(2), 100-115

20. Wang, C., Xia, Y., Li, W., Wilson, S. M., Bush, K., \& Peterson, G. Parenting behaviors, adolescent depressive symptoms, and problem behavior. Journal of Family Issues, 2016. 37(4), 520-542.

21. Muhtadie, L., Zhou, Q., Eisenberg, N., \& Wang, Y. Predicting internalizing problems in Chinese children: The unique and interactive effects of parenting and child temperament. Development and Psychopathology. 2013. 25(3), 653667.

22. Septiani, W. Hubungan Pola Asuh Demokratis dan Konsep Diri terhadap perkembangan Kecerdasan Emosional. Indonesian Journal of Guidance and Counseling: Theory and Application. 2017. 6 (3)

23. Novianty, A. Pengaruh Pola Asuh Otoriter terhadap Kecerdasarn Emosi pada Remaja Madya. Jurnal IImiah Psikologi. 2016. Vol. 9 No.1

24. Fitriana, V. \& Mustafida, S. Gambaran Pola Asuh Keluarga dengan Tingkat Depresi pada Remaja. Jurnal Profesi Keperawatan. 2019. Vol. 6, No. 1

25. Rarasati, N., Hakim, M. A., Yuniarti, K. W. Javanese Adolescents-Future Orientation and Support fot its Effort: An Indigenous Psychological Analysis. Word Academy of Science. 2012. 23 (6) 